\title{
Migration as a factor of development of the depopulating areas in East EU countries - The case of Lithuania
}

\author{
Donatas Burneika, Vidmantas Daugirdas, Rūta Ubarevičienė \\ Lithuanian Social Research Centre \\ A. Goštauto g. 11, LT-01108 Vilnius, Lithuania \\ donatas.geo@gmail.com; vidmantas.geo@gmail.com; ruta.ubareviciene@gmail.com
}

\begin{abstract}
Natural decrease and out-migration are the main processes causing depopulation of rural areas in most of the easternEU countries. The causes of depopulation are varied as well as numerous and might differ within the same country or even a region. Both internal and international migration play an important role inthepopulation decline in Lithuania, but their relative importance differ from region to region. Depopulation leads to a falling population density and therefore to the shrinkage of social networks, especially in the rural areas. It has broad consequences for the life quality, causes pessimistic attitudes and threatens the future development of the sparsely populated areas. There is little hope that the existing demographictrends will change in the nearest future. However, the analysed processes are usually perceived purely negatively, thoughit is not true in somerespects.
\end{abstract}

Keywords: sparsely populated areas, emigration, depopulation, rural development,Lithuania.

\section{Introduction}

Eastern European countries experience similar trends of the post-communist development which hasbeentaking place here since 1990s. Transformations from communist socio-economic system into neo-liberal one resulted in the fast changing economies and societies which required new spaces (Sýkora1999; Musil 1993; Marcińczak 2012; Brade et al. 2009). One could hardly deny that different societies tend to create different spaces, thus the transformation from quite even socialist countriesinto highly fragmented liberally organised capitalist ones should havesignificant spatial consequences.It is acknowledged that the spatial structures usually adapt to the new situation slower than the society that inhabits them(Logan 2012; Sýkora\&Bouzarovski 2012; Timár\&Váradi 2001). Therefore, the inherited spatial organization can still affect the preferences and decisions of the current society. In many cases this might mean a conflict between the old and new sociospatial structures. The older one tends to resist the changes and causeboth positive and negative consequences. It can reduce or facilitate the growth of the regional differences at the country level or prevent fragmentation and ghetto formation inside the cities. It can also paralyse development of the economy in the certain spaces or block the conversion of "grey" Soviet spaces into more pleasant ones. The different background can cause significantly different outcomes of the same processes 
in various countries. One of such structures, which are changing under the new socio-economic circumstances, is a settlement system.

The urban network of Lithuania was centrally planned and a balanced urban system was created during the Soviet period. It means that instead of the clear dominance of a capital city (in terms of the population and economy) an evenly developed network of regional and sub-regional centres was established in Lithuania. This is the opposite to what is found in many Western European capitalist countries of the same size. According to the simple logic and having in mind widespread trends of the concentration and metropolisation in the world, guided by liberal economic policies, the situation in Lithuania is subject to changes. We will try to explore the main trends of these processes in order to make some assumptions of the further development of the settlement system in Lithuania.

The aim of this paper is to reveal the main trends of the transformation of the Lithuanian settlement system related to the migration and metropolizationprocesses, which were taking placesince the restoration of Lithuanian independence in 1990. In this study we will explore the peculiarities of the depopulation process which results in the spreading of scarcely populated rural areas in the country.We will focus on the influence of the out-migration, which is one of the main causes of the on-going spatial and social processes.The results of the survey in the sparsely populated regions will be presented as well. We will also make some assumptions of the further development of the settlement system in Lithuania.

Massive internal and international migration processes (approx. 1.1 million people have participated in migration processes in the 3 million people country during the last decade, (Statistics Lithuania, 2013) can be (and often is) perceived as a tragedy or at least highly negative phenomenon. However, from the economical point of view it could be regarded as a usual relocation of the economic resources (labour in this case) underthe effective market economy (Arango 2000; Sjaastad 1962; Stark \& Bloom 1985). Therefore, international migration could be perceived as a phenomenon making whole economy of the EU more effective. We could saythe same about theinternal migration and its positive impact on the country's economy. Though there is little doubt that internal migration playsa positive role for the Lithuanian economy, it does not mean that it has always positive effect on the particular place. Sparsely populated areas may be qualified as the losers in this game, but apart from the negative consequences we must see positive ones. We may state that the socio-economic environment in the rural settlements would have been even much worse if there had been no emigration at all, considering the fact that employment in agriculture decreased more than 3 times since early nineties of the past century.

The research was funded by the Research Council of Lithuania (agreement No. SIN 02/2012).

\section{General trends inpopulation change in Lithuania}

Lithuania has the fastest rate of population decline in Europe and is one of the leaders in the World during the last decade (Fig. 1). 


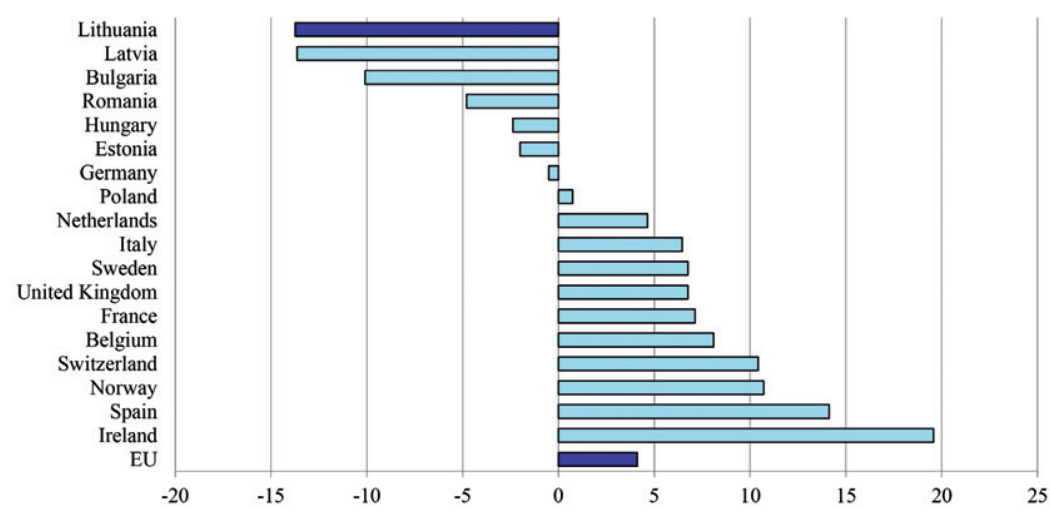

Figure 1. Population change (\%) in EU countries in 2000-2011 Source: http://epp.eurostat.ec.europa.eu.

Two interrelated processes have led to the extreme population decline of Lithuaniasince the early nineties of the last century - permanent negative natural decrease inthe population (Fig. 2) and constant negative net migration (Fig. 3).

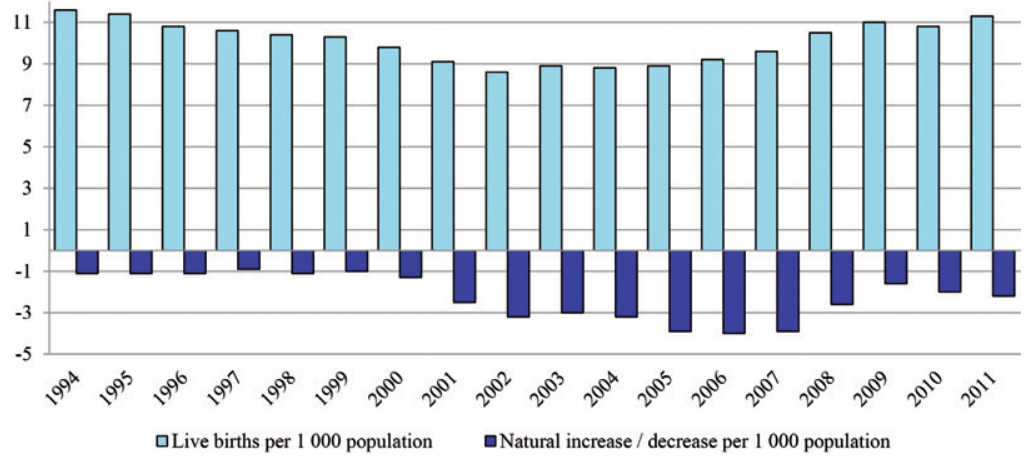

Figure 2. Natural population change in Lithuania in 1994-2011 Source: http://db1.stat.gov.lt.

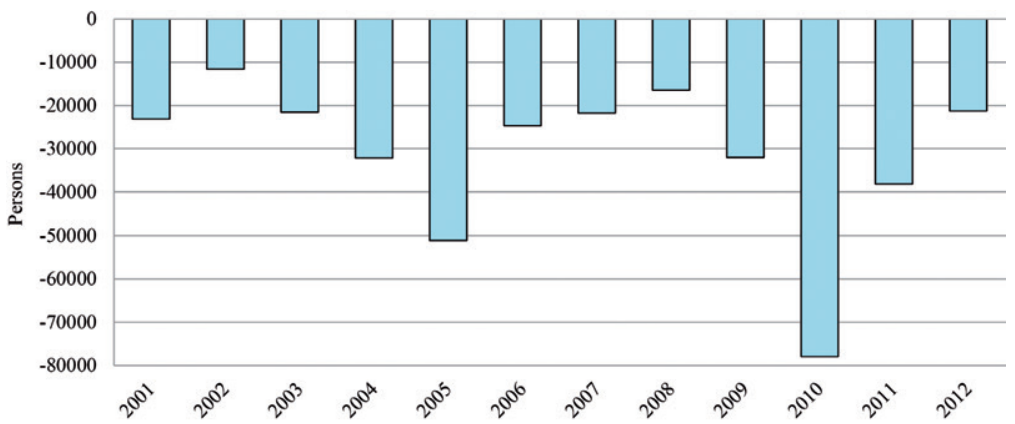

Figure 3. Net-migration in Lithuaniain 2001-2012

Source: http://db1.stat.gov.lt. 
Though thecountry as a whole loses population, there is a significant regional variation in population change. The highest population decline occurred in the peripheral parts (mostly rural areas) of the country and in the central parts of the medium-sized cities (e.g., Kaunas lost approx. quarter of its population in 1989-2011). According to the data of the recent censuses carried out in 2001 and 2011the trend remains the same. The only areas where the population number increased during the inter census period were the suburban zones of the major cities (Fig. 4).The similar trends of spatial development can be observed in all post-communist countries (Enyedi 1998; Gentile, Tammaru \& van Kempen 2012; Hamilton et al. 2005; Sailer-Fliege 1999; Sykora 1999; Smith \&Timár 2010). However, the specific settlement structure of Lithuania that was developed during the Soviet period, leaves us thinking that the spatial variations in population change are more profound here compared to the other countries.

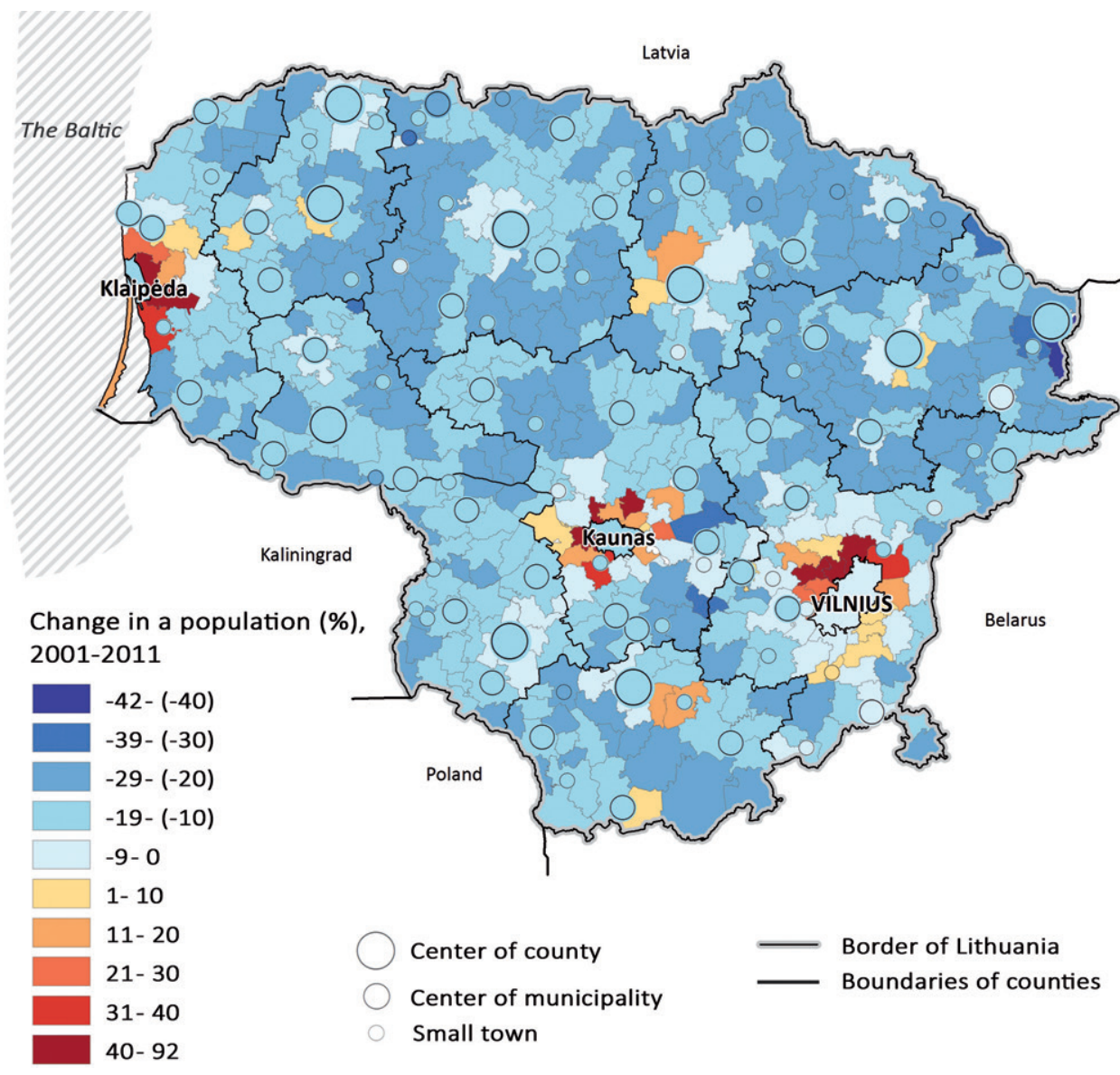

Figure 4. Population change in seniūnija (LAU 2 region) in 2001-2011 Source: 2001 and 2011 Lithuanian Census.

Deeper analysis of the on-going processes shows that the main cities play a decisive role explaining the population change across Lithuania. They also affect the distribution of the sparsely populated areas (Fig. 5). Cities and their metropolitan regions (mostly suburban and commuting 
areas) develop differently than the remaining country, andsparsely populated areas, as a rule,appear outside those zones. If the present trends continue, the population decline will persist until the sparsely populated rural areas include entire country outside the wider urban regions (commuting zones of the biggest cities).

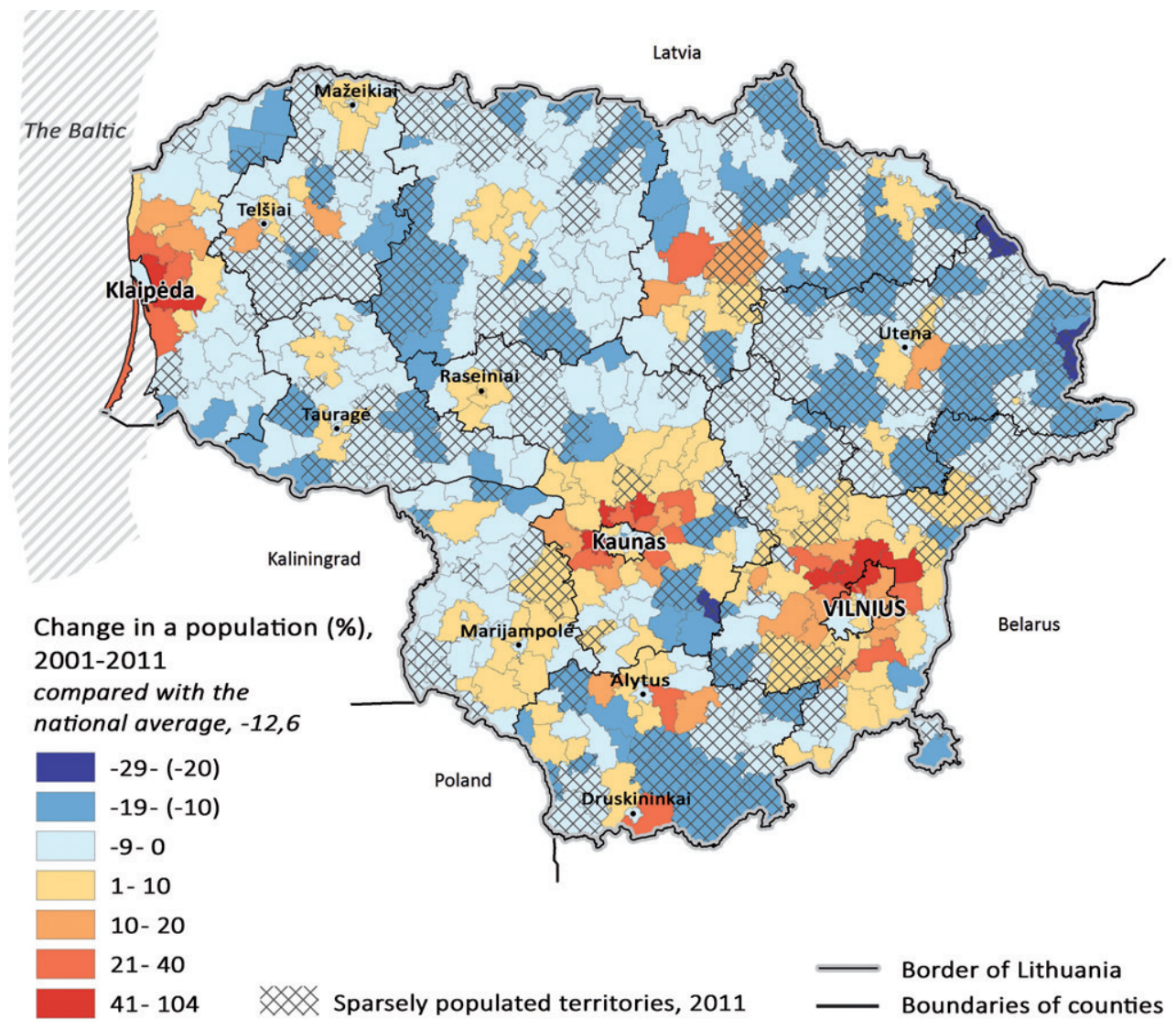

Figure 5. Relative population change in seniūnija in 2001-2011 and sparsely populated territories in Lithuania Source: 2001 and 2011 Lithuanian Census.

We suggest that the existing spatial misbalances of the development of Lithuaniaarethe result of the previous management of urban network, at least to some extent.Any society has more or less optimalspatial structure according to the state of its development and geographical structure of the country. A changing society means changing spatial structure which results in the redistribution of population.The greater the difference between the "optimal" and "actual" spatial structure of the society, the more difficult is to function efficiently for sucha society.Therefore, transformation of the former structures through the process of out-migrationcan be taken quite favourably, though very often it is perceived as a "tragedy". Of course, it has both positive and negative consequences.

The settlement system of Lithuania, which was greatly developed during the Soviet period, has quite distinctive featurescompared to other European countries of the similar size. Although, 
there have been significant socio-spatial transformation since the earlynineties of the past century, the settlement structure retained its main characteristics up to the present days. The Soviet planning policy was based on the idea of preventing the development of the biggest cities, especially Vilnius, and expansion of medium-sized towns into cities, giving them regional functions (several (initially 10, but eventually 6) evenly distributed centres were planned and developed across the country)(Vanagas\&Staniūnas 2000; Vanagas et al. 2002). There is no clearly dominant metropolitan city in Lithuaniaand the country is covered by a quite dense net of the medium- and small-size cities. The capital city of Vilnius was just slightly (by some 27 \%) bigger than the second largest city Kaunas in 1989. During the Soviet times rural population was evenly distributed to thecentral kolkhoz settlements (towns of few hundred inhabitants) scattered throughout the country. Meanwhile most of the farmsteads were annihilated duringthe Soviet era. On the other hand, the features of the settlement system at the highest level were alsoconditioned by the historical (rise of Kaunasis very much related to its capital city status in 1920-1939) and geographical (Vilnius is not a port city and it is located in the very eastern part of the country) reasons.

Because of the constant deficit of agricultural products in the Soviet Union and comparatively effective agriculture in the Soviet Lithuania (comparing to remaining Soviet Union), the Soviet regime was quite successful in preventing out-migration from ruralareas in order to sustain the labour forcethere, and so in diminishing the level of urbanization of country. The scheme was working quite well in the central planning system - in an economy without competition. However, the neo-liberal market economy completely changed this situation and the number of persons employed in agriculture dropped from 399.2 thous. in 1993 till 112.2 thous. in 2012, while the production level remained at more or less the same level (Statistics Lithuania, 2013). The drop is more than obvious, even though the numbers might be inaccurate, because different methods of data gathering were used. Under such circumstances mass out-migration from rural settlements is inevitable. All of thisleadsto the formation of the sparsely populated rural spaces, and enhances further negative trends of social development.Emigration of labour force reduces demand for commercial and non-commercial services. The shrinkage of social and commercial infrastructure not only facilitates emigration processes, but also substantially reduces quality of life in the rural areas. The number of residents is too small for keeping schools, post offices, bus connections, sometimes even shops and drugstores open.On the other hand, the impact of shrinkage on the majority of the local residents is less than it could be expected. An increasing mobility of the society reduces the demand for local services and provides alternative places for various needs. Finally,those whose mobility is lower (elderly population, poorer people, etc.) find themselves in the grip of the spatial exclusion.

When analysing the development trends of the sparsely populated areas, we are focusing on the processes taking place in the rural spaces. Fig.6 illustrates the trends inchanges of rural population. We may saythat notwithstanding the existing differences of age structure, birth rates, land use structure, etc., the rural population is shrinking very fast in whole Lithuania. Aging regions of the north-east Lithuaniahave the same trends in the rural population decline compared to the much younger western regions. Birth rate in the western Telsiaicounty was 10.8, while the eastern one Utena had just 7.9 births per 1000 residents in 2012 (Statistics Lithuania, 2013), differences among the rural residents are even greater. We may make an assumption that the population change depends not onthe processes of natural change. Higher natural increase just results in a higher outmigration,thus trends of depopulation remain the same. The decisive factor of population change is 
the diminishing "capacity" of the rural spaces to maintain population, mostly due to reduced labour demand in agriculture. The only exception could be found in the suburban areas where the growth of rural population is purely "statistical".

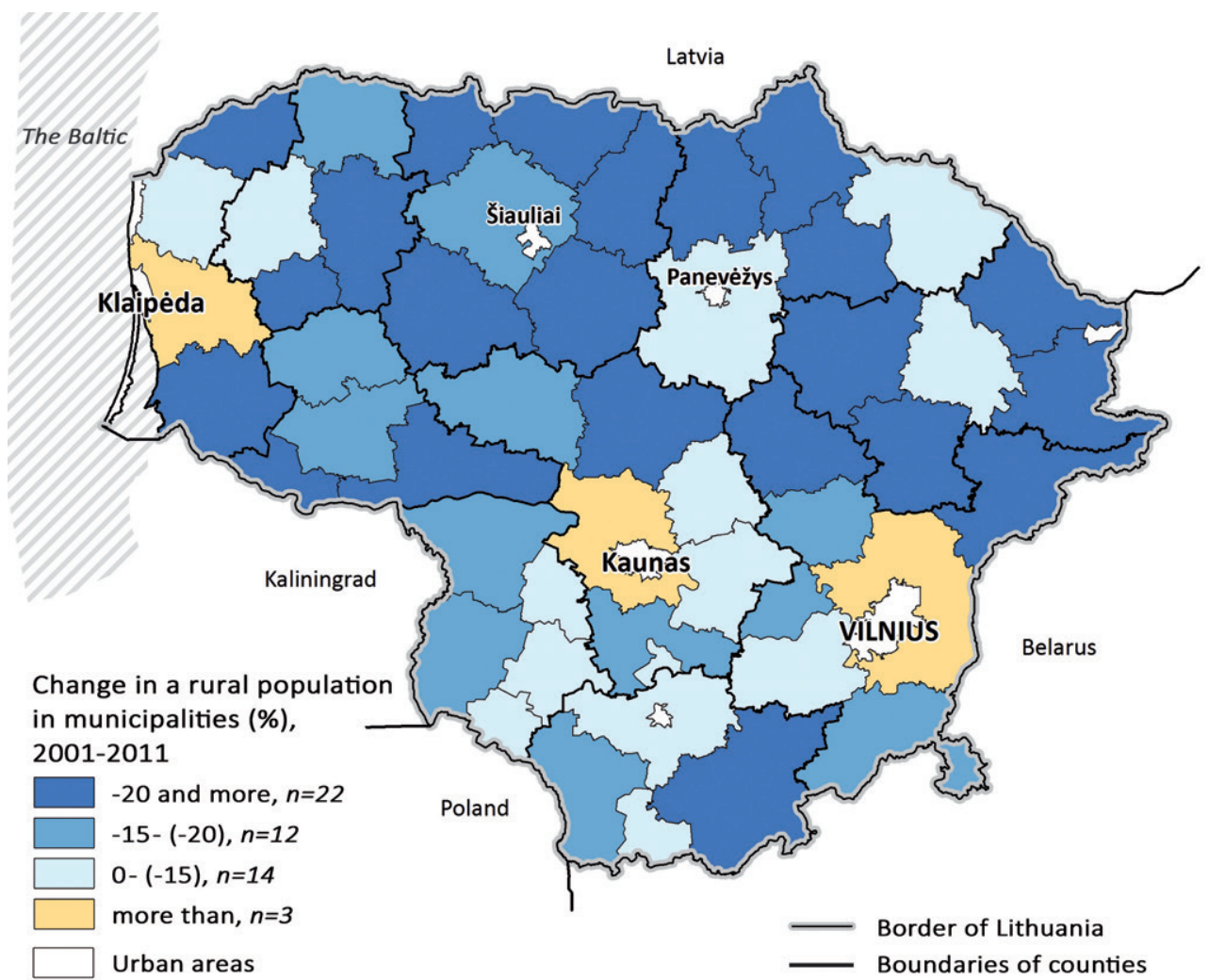

Figure 6. Rural population change in municipalities in 2001-2012 Source: 2001 and 2011 Lithuanian Census.

One of the outcomes of depopulation is a fast spread of sparsely populated areas. The number of rural LAU 2 (seniūnija) regions, where the density of population is less than 12.5 persons per square kilometre,more than doubled during the last decade (Fig.7). The decrease in population densityresults in a gradual shrinkage of the network of social and commercial infrastructure. For example, the number of schools diminishedby more than $70 \%$ in some north-eastern municipalities (Burneika et al. 2013). 

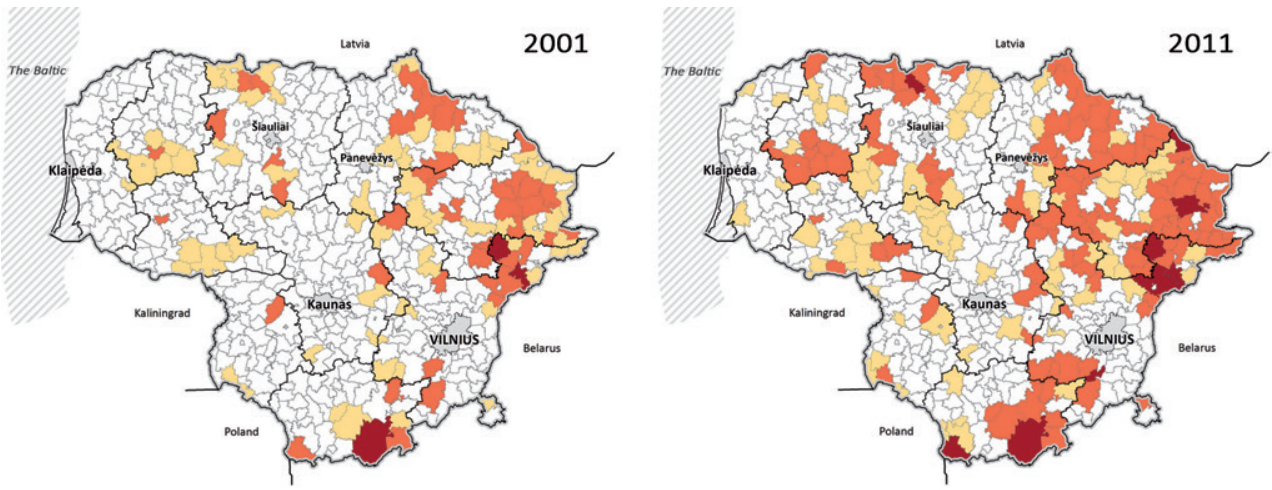

Density of rural population, $\mathrm{km}^{2}$

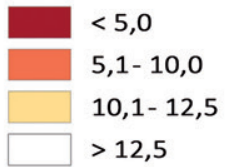

Main cities

Border of Lithuania

Boundaries of counties

Figure 7. Extentof the sparsely populated LAU 2 regions across Lithuania in 2001-2011 Source: 2001 and 2011 Lithuanian Census.

\section{Emigration processes in Lithuanian municipalities}

The present process of arapid decline of the population and its spatial redistribution within the country is very likely a result of the artificially constrained urbanization and metropolization processes during the Soviet period. Unemployment, wage differences, images of the places and other reasons that determine migrations are well known, but they can hardlyexplain the exceptional scale of the depopulationin Lithuania (Arango 2000; Abreu 2010; Boyle et al.1998). Unusual spatial structure (settlement system) of the country might beone of the alternative answers.Redistribution of population from rural areas and towns to urban areas and especially to metropolitan regions is absolutely natural process taking placein all developing countries and in post-communist states in particular (Boren \& Gentile 2007). Best jobs are concentrated in the biggest metropolitan areas due to the comparative advantages they can offer, though this can have many negative aspects as well. Therefore, many citizens outside the metropolitan areas do not have any choice between "to emigrate or not to emigrate?"They only have an option - "where to?" And they make choices according to their subjective perceptions of the places.

Emigration is a natural process, which gained "unnaturally high" and exceptional character due to the decline of political, economic and "mental" borders in EU and because of the specific settlement structure of Lithuania.We could monitor processes taking place in the country, which instantly was transformed from positive periphery of the Soviet Union into negative periphery of EU. There are no possibilities to change peripheral status of the country, but the former history and examples of other EU member states (Ireland, Finland) suggest that periphery is not necessarily a place with negative trends of development and images. Peripherisation of the country is followed by peripherisation of many places inside the country and all this leads to the rise of out-migration. There is almost no chance to stop migration, but maybe it is possible to regulate itby changing the 
destinations of those leaving their hometowns. Instead of coping with the process (trying to keep "loyal" voters in the same place - ruling parties rely on the support of the peripheral citizens, which compose the majority of active voters), maybe it would be wise try to offer alternative destinations for migrants, which would be inside the country.

We used data from the Department of Statistics of Lithuania to analyse the trends of the migration from the municipalities. We used data on the level of municipalities (which also include urban population), because there is no migration data available for a lower level. On the other hand, the majority of sparsely populatedmunicipalities (density of rural population is less than 12.5 residents per sq. $\mathrm{km}$ ) do not have big urban centres, thereforethe general data provide quite objective view on migration trends namely from the rural areas. We found out that the ruralpopulation participates more in theinternal migrations compared tothe bigger cities (Fig.8, left).Therefore,the general data of the internal migrationsfor municipality provide quite reliable picture of rural spaces. International migration has different character, where the main cities play much more important role (Fig. 8, right). Therefore, it would be not correct to interpret the processes in the rural areas (especially in the eastern Lithuania).
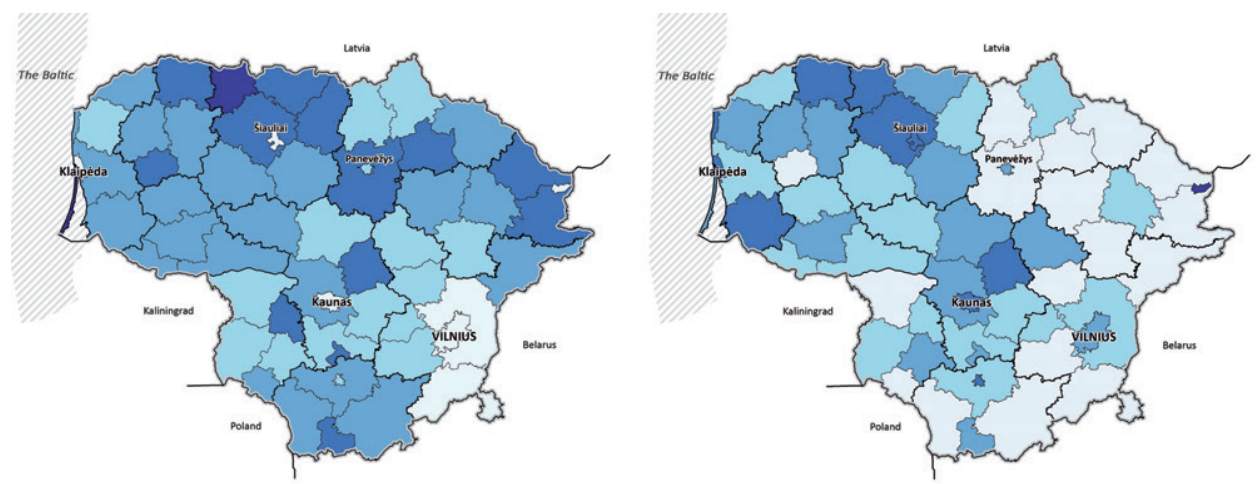

Average proportion of yearly emigrants from municipalities (\% of total population in 2001-2012) Internal migration

$0,8-1,4$ International migration

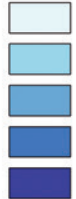

$1,5-1,7$

$1,8-2,0$

$2,1-2,5$

$2,6-3,2$

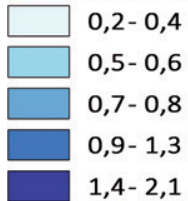

Border of Lithuania

Boundaries of counties

Figure 8. Differences in internal and international migration from Lithuanian municipalities in 2001-2012 Source: Statistics Lithuania, 2013.

Though main drivers of emigration are quite similar everywhere (mostly related to the lack of better paid jobs), substantial differences between western and eastern Lithuania exist, especially in terms of international migration.This can be partly explained by the different demographic situation (first of all by age structure of rural population). However, other factors play alsoa role. We suggest that differences are also related to geographical and historical background. For example, areas that are located further from the Vilnius metropolitan region have higher share of international migration (Fig.8, right).Internal migrations also have similar pattern. Historically, due to the multi-nodal urban structure, many western municipalities of Lithuania used to have quite weak social relations with 
the capital city. International migration, which started during the deep economic recession in the early nineties, rapidly created a situation, where many local residents had more social contacts with Western Europethan with Vilnius. Therefore,adecision to leaveabroad is more favourable even from psychological point of view (not to mention the differences in wage). Of course local (site) factors are also important in some cases (like closure of big companies, such as Ignalina nuclear power plant in Visaginas), but those are more important in urban spaces.

\section{Emigration from sparsely populated municipalities}

Increasing rates of migration from the peripheral municipalities in the western part of Lithuanian put the sparsely populated areas among the leaders of emigration, while migration from the major cities was dominating in the beginning of the period. We also have to stressthat the significant differences appeared and the spatial pattern of migration has changed substantially during the analysed period. The growth of the out-migration was the general trend throughout the country. The international migration reached its peak in 2010, when economic crisis hit Lithuania and especially its metropolitan areas, where the sectors of industry and construction were concentrated. Although the actual number of migrants is not precise, an increase of international migration and decrease of internal one were noticeable(Fig. 9 and 10). The increase in the share of the international migration was also due to the changes in the state social insurance requirements in 2010, which resulted in a massive formalisation of the emigration status, therebyavoiding the paymentobligatory insurance contributions.

The opposite trends intheinternal and international migrations, which were clearly obvious during the last years, once again confirm our assumption that the decision to emigrateisoften inevitable, but thedestination can be affectedby various factors.

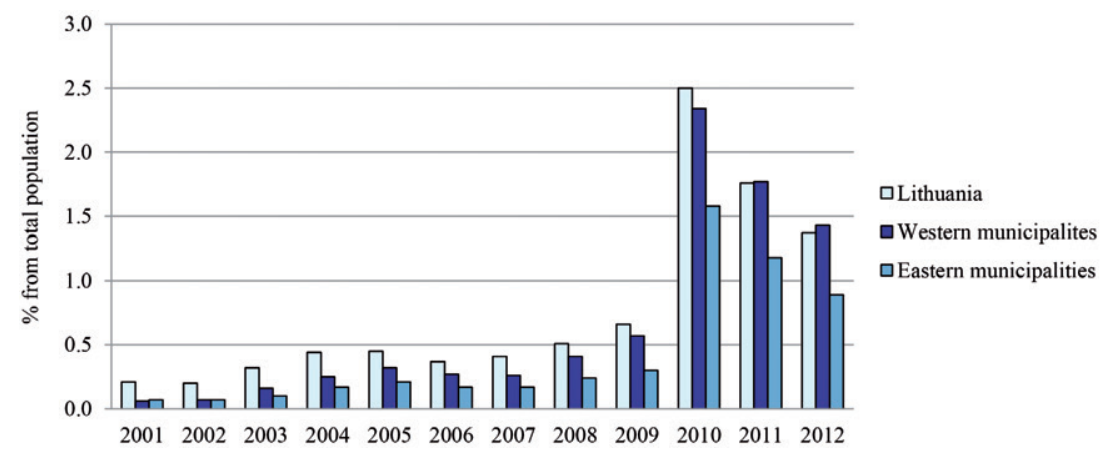

Figure 9. Trends ininternational out-migration from the sparsely populated municipalities in 2001-2012 


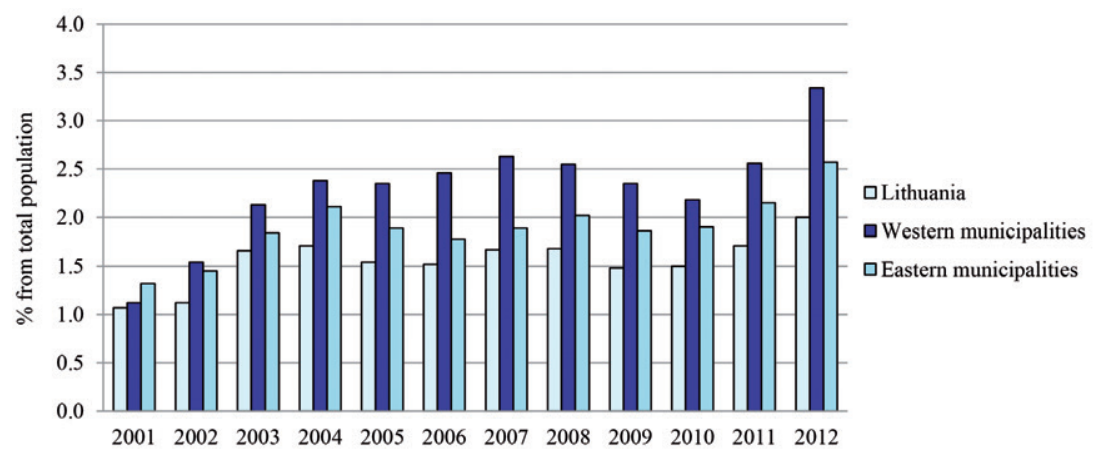

Figure 10. Trends ininternal out-migration from the sparsely populated municipalities in 2001-2012

The differences between the eastern Lithuanian municipalities, which suffer the negative socioeconomic trends, and the western ones, can be spotted easily. Both international and internal migrationhas peculiarities. At the beginning of the analysed period, cities played a dominant role in the flow of international migration, while both eastern and western sparsely populated municipalities produced $2-3$ times less intensive flows of emigrants. The "migrability" of the western municipalities has been growing very fast and now they are producing relatively more intenseoutflowof the population compared to the rest of the country.

The intensity of migration also grew in the eastern Lithuania, but it did not reach countries' average (mostly due to the lack of younger residents or vicinity of Vilnius). The spatial patternof the relative migration flows has changed substantiallybetween 2001 and 2012 (Fig. 11 and 12). There were no essential differences in the socio-economic development of municipalities during the last decade; therefore we may make an assumption that the increase in out-migration is at least partly related to the process of escalation of migration, when emigrational decisions are becoming more and more natural for residents of peripheral municipalities. The lack of the attractive jobs and stronger economic centres in a commuting range also facilitates out-migration fromthe north-western municipalities of Lithuania, which are located further from the main metropolitan centres of the country.

An analysis of depopulation reveals that the internal migration used to be more important factor than the international one in the sparsely populated municipalities. However the situation has changed in the recent years. While theinternal migration remained quite stable, international one grewfast, especially in the western municipalities. The traditional north-eastern "problem" region, which was dominatingin theinternal and international out-migration flows in 2001, lost its relative importance in 2012. 

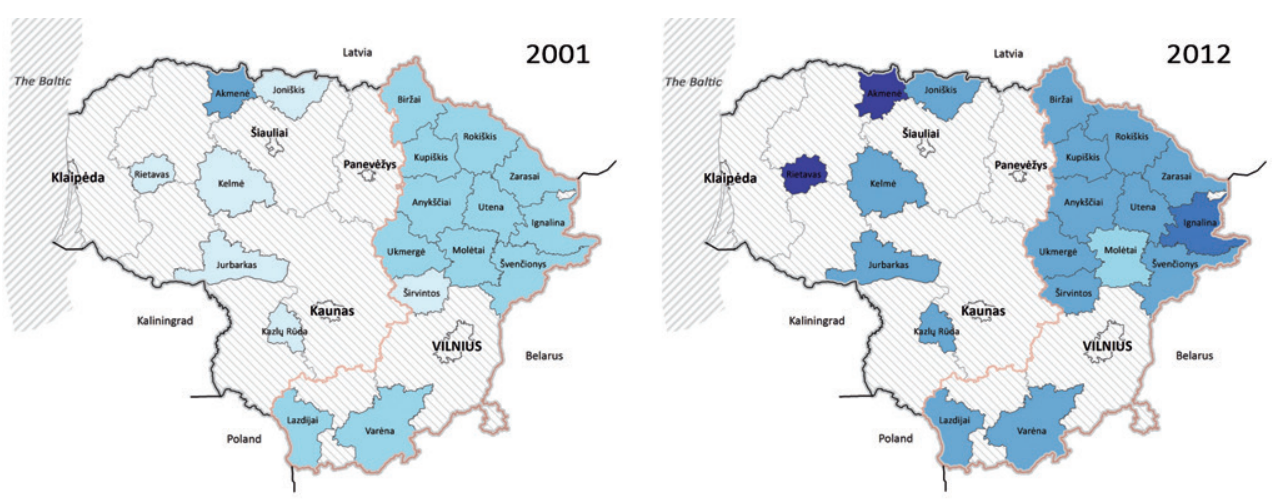

Internal out-migration (\%) from the sparsely populated municipalities
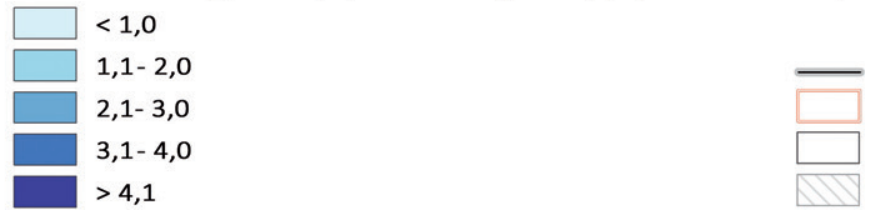

Border of Lithuania Eastern Lithuania Main cities

Non-sparsely populated areas

Figure 11. Internalout-migration from the sparsely populated areas in 2001 and 2012 Source: Statistics Lithuania, 2013.
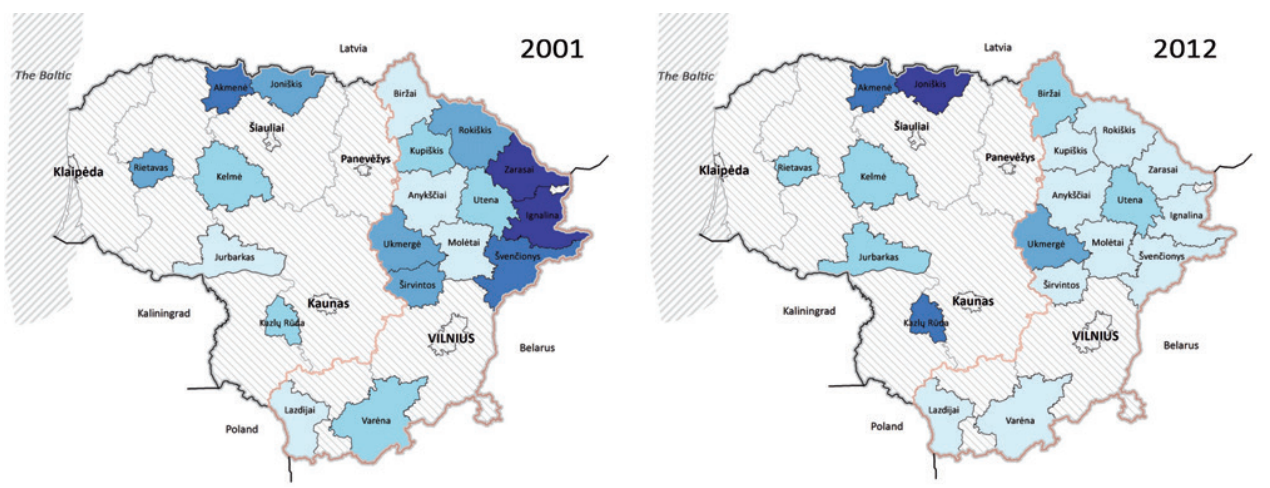

International out-migration (\%) from the sparsely populated municipalities

2001

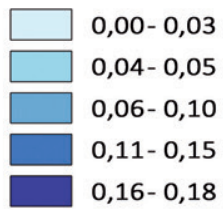

2012

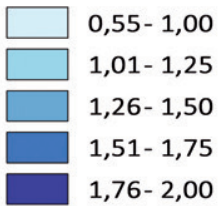

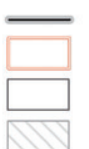

Border of Lithuania Eastern Lithuania Main cities

Non-sparsely populated areas

Figure 12. Internationalout-migration from the sparsely populated areas in 2001 and 2012. Source: Statistics Lithuania, 2013. 


\section{Spatial pattern of internal migration in Lithuania}

There are no statistical data on destination of migration within or betweenmunicipalities in Lithuania. Authors tryto showthe spatial pattern of flows of the population using thedata of the redistribution of residents' income tax (according to the official place of residence of employees) from the Lithuanian State Tax Inspectorate. We expect that thesedata couldreveal the discrepancybetween the place of work and the official place of residence of employees. Thesedifferences come upmostly when people do not declare their new permanent or temporary place of residence (because of the various reasons), or commute to jobs, which arelocated in othermunicipalities. Substantial commuting flows mostly involve areas up to $40 \mathrm{~km}$ around the biggest cities; therefore the data on sparsely populated areas, which are situated further, can be used to indicatethehidden flows of migration from those places to the cities. Even though by using the data from the State Tax Inspectorate, we cannot accurately evaluate the volume of migration flows between the municipalities, such data can show the dominant destinations, and they can illustrate the hidden flows of migration, which cannot be measured by usual methods. The fact that theredistribution of taxes exists indicates that the actual migration ismuch more higherthan it is declaredby statistics. For example, according to the redistributed amount of income tax, we may assume that some 75 -80 thous.employees of Vilniusdo not reside in the cityofficially (around25-30\% of Vilnius's tax payers). It equals to the total number of employees in the third largest city of Klaipeda.

Residents of the sparsely populated municipalities are most likely to find jobs (and homes) in the cities. The choice of the particular city depends on its size, status, relative importance and location (Fig. 13). The latter factor is especially important in the vicinity of the County'scentres, because of the commuting opportunities. Therefore,the cities sometimes play a stabilizing role fordepopulation. We may say that the capital city of Vilnius is the most important point of destination for migrants from across thecountry, except for the closest municipalities of theother County's centres. The comparison of the situations in 2008 and 2012 allowsus to saythat the relative importance of Vilnius is growing even in more distant municipalities (Jurbarkas, Lazdijai and others). This illustrates the intensification of the metropolisation processes.

Vilnius city is the main destination for migrants from all over the country. Meantime, Kaunas and Klaipedaplay an important role in the middle and western parts of the country respectively.Other cities have only small regional impact and they are mostly destination points for labour migrants inside the commuting zone.

One of the main drivers of the discussed trends is obviously associated with the differences inthe economic development. The levelof concentration of the economy is much higher in Lithuania than the levelof populations' concentration.Once again thisconfirms the argument that the social and economic structure changes much faster than the space. More than $45 \%$ of the total income tax of Lithuania is gathered in Vilnius, while officially the city is inhabited only by $17,8 \%$ of thetotal population. One could expect that the tendency of metropolization will continue in the future, because cities offer much better opportunities. 

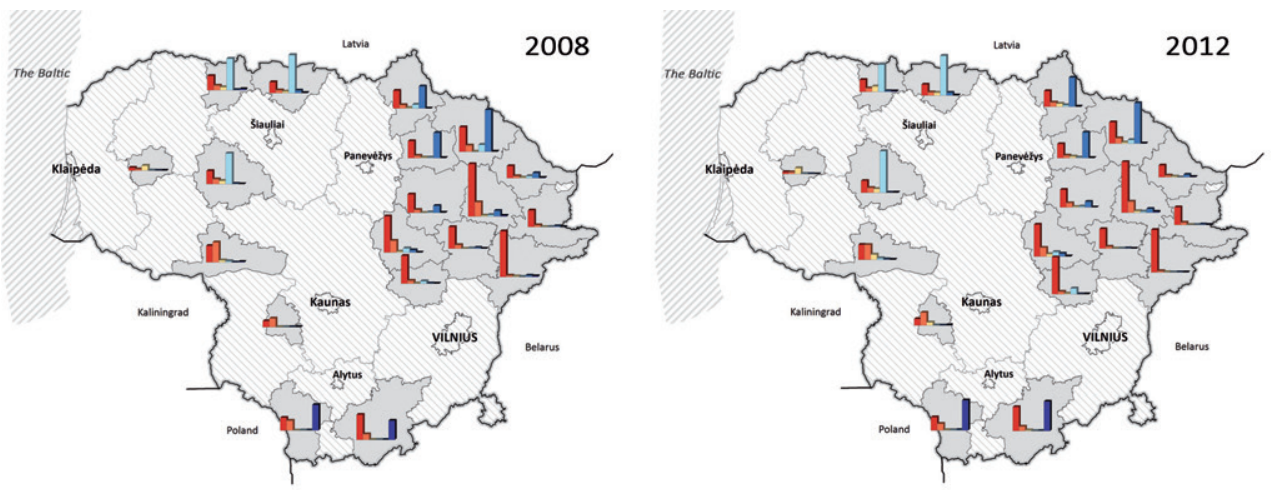

Number of labour migrants to the major cities according to the redistribution of the residents income tax
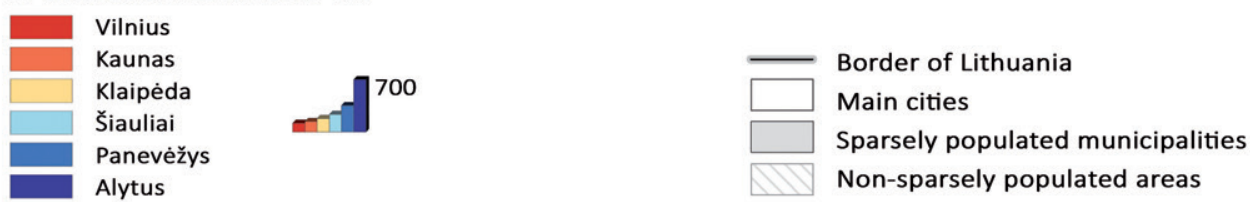

Figure 13. The destinations of labour migrants from sparsely populated municipalities to the major cities Source: State Tax Inspectorate, 2013.

\section{Results of quantitative research of residents of sparsely populated areas}

In order to understand better the factors fuelling migration processes and depopulation of rural settlements, a survey was carried out among the residents of the sparsely populated LAU 2 regions. 602 residents were questioned in different parts of Lithuania in 2012. The structure (gender and age) of the interviewed residents corresponded to the existing structure of the rural population in different regions. $60 \%$ percent of the respondents were females. The age composition was as follows: $20 \%$ under the age of 36, 57\% between 36-65, 23\% were above the age of 65 .

The results of the surveyindicated that $15 \%$ of the residents intend to leave their town in the nearest future, therefore, the emigration processes will persist, though itspace should not increase. Sucha comparativelysmall number is related to the existing age structure of the analysed rural areas. $46 \%$ out of 124 questioned young respondents (less than 36 years old) intend to leave their hometowns. The average age of those planning to emigrate is 34.1. Average age of those planning to stay is 54.2. The majority of those who plan to emigrate are going to go to one of the regional centres of Lithuania or abroad (51\% and 38\% respectively). This illustratesthe trends of metropolisation, urbanisation and concentration of population in Lithuania and in EU.

The urbanisation of the country takes place at the level of the biggest cities. Only one respondent said that he was going to moveto the local urban centre. The micro level location of the respondents is not a decisive factor for thedecision tomigrate. Jobs at the municipal centre are easily reachable for the residents of the entiremunicipality. Only $20.6 \%$ of the respondents indicated that they werenot satisfied with the main services in their living place. However, themajority of those who were unsatisfied were not able to name what kind of services theylack. The majority of "future 
emigrants" (57\%) indicated that the employment was the main reason oftheir decision. "Family related" reasons dominated among the older population. Interestingly, none of the younger than 51 years old respondents motivated their decision by the "family related" reasons. Education and better prospect were also mentioned as the reasons ofemigration. 17\% of those planning to leave were not able to indicate any particular reasonof their decision; therefore, we may presume that the main reason for their out-migration was a wish just to emigrate.

$10 \%$ of those planning to leave indicated that they liked everything in their local region.However, the main advantages of their current place of residence, which they have mentioned could be attributed to the common features of peripheral places (quietness, nice and clean environment, etc.). Theseare the characteristics illustrating the good quality of the environment, but poorlyassociated with the unfavourable conditions for job creation or development of the entrepreneurship.

$85 \%$ of therespondents stated that the number of population intheir local region should grow in the future, while the minority of the samerespondents saw good perspectives for the youngergeneration. Most of the respondents indicated that their region was most suitable for agriculture. However, anincreasing technical base in the agriculture will hardly raise the demand for labour force in the nearest future. The hypothetic need for the growth of population is mostlyrelated to thenostalgia of the former era of "prosperous growing" village. Traditionally,the prosperity is related to the growth of population; therefore,out-migration and depopulation automatically will be regarded as negative trends - sourcefor problems, but not an outcome of the processes (see more Martinez-Fernandez et al. 2012; Haartsen\&Venhorst2009; Bontje 2004). Therefore, we may assume that the negative social consequences of the present population declinecould be substantially mitigated by providing better understanding of on-going processes. More objective expectations would minimise pessimistic moods related to the routine shrinkage of the rural settlements.

\section{Conclusions}

The spread of the sparsely populated rural areas is a consequence of the transformation fromthe Soviet planned settlement system toa new society and economy guided by the neo-liberal principles. The post-soviet transitionis taking place along with the processes of concentration, metropolization and peripherisation that are common inmany places ofthe globalised world. Natural processes of depopulation of the rural areas and shrinkage of the medium size towns are related to the delayed urbanisation and metropolization. These processeswill continuein Lithuania and in other countries of the post-communist region in the nearest future. First of all, this will make negative impact on the local population by damaging expectations and hopes, but not incomes or living standards.

We assume, that the process of metropolization will continue in Lithuania, but it will take a long time until the degree, which exists in the remaining Europe, including the Baltic States, will be reached. The trends of metropolization will be expressed more via the shrinkage of the secondary cities than by expansion of the capital city-region. Such a situation and the inherited polycentrism of the country tends to lead to the higher flows of out-migration in Lithuania compared to other post-socialist countries. The spatial differences of the on-going socio-economic and spatial transformations mightcause various social, economic and psychological tensions in the future. Any attempts to prevent metropolization by seeking methods to keep population in the medium-sized cities and towns wouldfail or even accelerate migration flows from the country. Therefore, the management of the settlement network and regional development should be based on the idea of solidarity and 
unity, but not on the attempts to sustain uniform settlement network or even economic activities across the county.

The process of depopulation of the rural areas is mostlyrelated to the shrinkage of jobs in agricultural sector and with other socio-economic reasons than it is dependedonthenatural change of population. Differences in fertility rate, age structure of population and other demographic factors make little influence on the pace of depopulation in different municipalities.There are very few possibilities to stop out-migration from the rural areasuntil the rural population will reach its natural size; therefore governmental policy should be focusedon regulation of destinations of migrationflows trying to promote residential mobility inside the country instead of trying to prevent it at all. Creation of more positive image of the main cities and the country itself, and housing support for young families in the growing metropolitan areas could help to achieve this task. A reorganization of the regionalgovernance and establishment of self-government at the community level are among those few measures, which could help to mitigate both internal and international migration, which originates not because of reducing capacity of rural areas to withhold population, but because of the loss of sense of local identity, subjective negative expectations and other similar reasons.

\section{References}

Abreu A., 2012. The new economics of labor migration: beware of Neoclassicals bearing gifts. Forum for social economics. Abingdon: Routledge, pp. 46-67.

Arango J., 2000. Explaining migration: a critical view. International Social Science Journal, vol. 52, no. 165, pp. 283-296.

Bontje M., 2004. Facing the challenge of shrinking cities in East Germany: The case of Leipzig. GeoJournal, vol. 61, no. 1, pp. 13-21.

Boren T.,Gentile M., 2007. Metropolitan processes in post-communist communist states: an introduction. GeografiskaAnnaler, vol. 89, no. 2, pp. 95-110.

Boyle P., Halfacree K., Robinson V., 1998. Exploring contemporary migration. New York: Addison Wesley Longman.

Brade I., Herfert G., Wiest K., 2009. Recent trends and future prospects of socio-spatial differentiation in urban regions of Central and Eastern Europe: A lull before the storm? Cities, vol. 26, no. 5, pp. 233-244.

Burneika D., Daugirdas V., Kriaučiūnas E., Ribokas G., Ubarevičienė R., 2013. Socio-economical aspects of depopulation in Eastern EU border region - case of Eastern Lithuania. Region and regionalism, vol. 11, pp. 195-215.ENYEDI G., (1998). Transformation in central European postsocialist cities. Enyedi, G. (ed.) Social Change and Urban Restructuring in Central Europe. Budapest: AkadémiaiKiadó, pp. 109-136.

Enyedi G., 1998. Transformation in Central European postsocialist cities. Discussion Papers, 21, pp. 5-47. EUROSTAT, http://epp.eurostat.ec.europa.eu [14 September 2013]

Gentile M., Tammaru T., Van Kempen R., 2012. Heteropolitanization: Social and spatial change in Central and East European Cities. Cities, vol. 29, no. 5, pp. 291-350.

Haartsen T., Venhorst V., 2009. Planning for decline: anticipation on population decline in the Netherlands. Tijdschrift voor economische en sociale geografie, vol. 101, no. 2, pp. 218-227.

Hamilton F.E.I., Andrews K.D., Pichler-Milanovic N., 2005. Transformation of Cities in Central and Eastern Europe - Towards Globalization. Tokyo: United Nations University Press. 
Logan J. R., 2013. Making a place for space: Spatial thinking in social science. Annual Review of Sociology, vol. 38, pp. 507-524.

Marcińczak S., 2012. The evolution of spatial patterns of residential segregation in Central European Cities: The Lódź Functional Urban Region from mature socialism to mature post-socialism. Cities, vol. 29, no. 5, pp. 300-309.

Martinez-Fernandez C., Audirac I., Fol S., Cunningham-Sabot E., 2012. Shrinking cities: Urban challenges of globalization. International Journal of Urban and regional Research, vol. 36, no. 2, pp. 213-225.

Musil J., 1993. Changing urban systems in post-communist societies in Central Europe analysis and prediction. Urban Studies, vol. 30, no. 6, pp. 899-905.

Sailer-Fliege U., 1999. Characteristics of post-socialist urban transformation in East central Europe. GeoJournal, vol. 49, pp. 7-16.

Sjaastad L. A., 1962. The costs and returns of human migration. Journal of Political Economy, vol. 70, no. 5, pp. 80-93.

Smith A., Timár J., 2010. Uneven transformations: Space, economy and society 20 years after the collapse of state socialism. European Urban and Regional Studies, vol. 17, no. 2, pp. 115-125.

Stark O., Bloom D. E., 1985. The new economics of labour migration. The American Economic Review, vol. 75, no. 2, pp. 173-178.

State Tax Inspectorate, http://www.vmi.lt/lt/?itemId=10121222 [10 February , 201302 10].

Statistics Lithuania, 2013. http://db1.stat.gov.lt/statbank/default.asp?w=1920 [5 February, 201302 05].

Sýkora L., 1999. Processes of socio-spatial differentiation in post-communist Prague. Housing Studies, vol. 14, no. 5, pp. 679-701.Sýkora L., Bouzarovski S., 2012. Multiple transformations: Conceptualising the post-communist urban transition. Urban Studies, vol., 49, no. 1, pp. 43-60.

Sýkora L., Bouzarovski S., 2012. Multiple TransformationsConceptualising the Post-communist Urban Transition. Urban Studies, vol. 49, no. 1, pp. 43-60.

Timár J., Váradi M. M., 2001. The uneven development of suburbanization during transition in Hungary. European Urban and Regional Studies, vol. 8, no. 4, pp. 349-360.

Vanagas J., Krišjane Z., Noorkoiv R., Staniūnas A., 2002. Planning urban systems in Soviet times and in the era of transition: The case of Estonia, Latvia and Lithuania. GeographiaPolonica, vol. 75, no. 2, pp. 75-100.

Vanagas J., Staniūnas E., 2000. The Lithuanian urban system. Working - paper - Urban system and urban networking in the Baltic Sea region. Gdansk, pp. 145-167. 


\section{ALL VOLUMES OF EUROPA XXI}

26 (2014) : The role of territorial capital in development polices

25 (2014) : Detecting Territorial Potentials and Challenges

24 (2013) : Transport accessibility at regional scale in Europe

23 (2013) : Services of General Interest in European Union

22 (2012) : Territorial development and cohesion in a multi-scalar perspective

21 (2010) : Environmental and infrastructural networks

20 (2010) : European Union: external and internal borders, interactions and networks

19 (2009) : European urban system: metropolization and networking

18 (2008) : Territorial dilemmas of socio-economic development in Europe

17 (2008) : New functions of rural and industrial space in Central and Eastern Europe

16 (2007) : Regional development in Central Europe - cohesion or competitiveness

15 (2006) : Regional periphery in Central and Eastern Europe

14 (2006) : Core and peripheral regions in Central and Eastern Europe

13 (2005) : New spatial relations in new Europe

12 (2005) : Central and Eastern Europe: changing spatial patterns of human activity

11 (2004) : Przestrzeń Europy. Przestrzeń Unii Europejskiej

10 (2003) : Society and environment. Towns and settlement in Europe

9 (2003) : Polska i Europa: kształtowanie przestrzeni wolności

8 (2003) : European space in the face of enlargement: the West to East European Trajectory project

7 (2002) : Slovakia and Poland: urban, social and demographic questions, relations between neighbours

6 (2001) : Integracja europejska - dylematy spójności i konwergencji regionalnej

5 (2000) : Przestrzeń ekologiczna Polski. Dekolektywizacja rolnictwa

i sytuacja zdrowotna w Europie Środkowej,

Wschodniej i Południowo-Wschodniej

4 (2000) : Powiązania handlowe Polski z Europą. Z debaty

o przyszłym kształcie zjednoczonej Europy

3 (1999) : Obszary szczególnej troski i nowych możliwości rozwoju na przykładzie Polski i Ukrainy

2 (1998) : Przestrzeń Europy Środkowej - przykłady transformacji

1 (1998) : Sieć komunikacyjna Polski w europejskich procesach integracyjnych 


\section{Territorial capital in practice - environmental and social issues}

- Małgorzata Kowalczyk, Paweł Sudra Ecosystem services in spatial planning

- Marta Deptuła Ecosystem services of Kampinos National Park for the city of Warsaw

- Viktor Varju

The need for an effective and integrated environmental policy: lessons from Hungary

- Aleksandra Lyubenova Ravnachka Educational infrastructure of Blagoevgrad District - a factor of labour demand and supply in the labour market (2001 2011)

- Nadezhda Borissova llieva The Roma people in Bulgaria - their number and localization, from the Liberation (1878) until the beginning of the 21st Century

- Donatas Burneika, Vidmantas Daugirdas, Rūta Ubarevičiené Migration as a factor of development of the depopulating areas in Eastern EU countries. The case of Lithuania

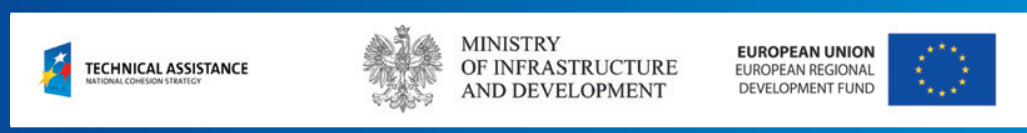

